\title{
THE BIOLOGY OF THE SPIDER WASP, PEPSIS THISBE (HYMENOPTERA: POMPILIDAE) FROM TRANS PECOS, TEXAS. I. ADULT MORPHOMETRICS, LARVAL DEVELOPMENT AND THE ONTOGENY OF LARVAL FEEDING PATTERNS
}

\author{
By FRED PUnZo \\ Department of Biology \\ Box 5F \\ University of Tampa \\ Tampa, FL 33606
}

\begin{abstract}
Aspects of the natural history and behavioral ecology of the spider wasp, Pepsis thisbe were studied in Trans Pecos, Texas with special emphasis on larval development and host interactions. Additional parameters studied include the physical dimensions of the egg, larval and adult size, fecundity, egg survivorship and duration of embryonic and postembryonic development as a function of temperature and relative humidity $(\mathrm{RH})$, larval growth and behavior, the relationship between adult wasp and host sizes, and ontogenetic changes in larval feeding patterns. Eggs and larvae did not survive when exposed to xeric conditions (10\% RH). Forty-one days were required to progress from egg to emerged adult at $30^{\circ} \mathrm{C}$ and $70 \% \mathrm{RH}$.
\end{abstract}

\section{INTRODUCTION}

The genus Pepsis (Hymenoptera : Pompilidae), comprising numerous species, is found in North and South America, and the West Indies, ranging from Utah (latitude $42^{\circ} \mathrm{N}$ ) to Argentina $\left(47^{\circ} \mathrm{S}\right)$ (Hurd, 1952). Fifteen species are found within the Nearctic region. Wasps in this genus are characterized by the following behavioral traits: 1) utilization of spiders as a larval food source with each wasp larva provided with a single paralyzed host, 2) the female wasp drags the paralyzed host backwards over the ground

Manuscript received 22 August 1994. 
and places it in a nest (burrow), 3) a single egg is attached to the abdomen of the spider and, 4) the abdomen of the wasp is used to compress the loose soil in the closure of the nest entrance (Evans, 1953; Evans and Yoshimoto, 1962).

Adult male and female Pepsis wasps are nectivorous, and females utilize mygalomorph spiders almost exclusively as a food source for their carnivorous larvae (Hurd, 1952; Cazier and Mortenson, 1964; Punzo and Garman, 1989; Punzo, 1990, 1991). For this reason, these wasps have been frequently referred to as tarantula hawks (Passmore, 1936; Petrunkevitch, 1926, 1952; Williams, 1956). Relatively little is known concerning the comparative life histories of these spider wasps (Evans, 1953; Alcock, 1983).

This paper describes various aspects of the biology and natural history of Pepsis thisbe Lucas from the Big Bend Region of Trans Pecos, Texas. I report data collected from field studies and laboratory experiments conducted from 1985 to the present time. Most of the field data were collected during late spring through the summer (April-September) except for 1986 when I spent eight months in the field (May-January). Wasps and hosts were transported to the University of Tampa (UT) as described by Punzo (1990) where laboratory studies were conducted. My objectives were to determine or describe: 1) physical dimensions of the egg (length, width, and weight), 2) larval and adult size (total body length, head capsule width, and wing length), 3) survivorship and duration of embryonic and postembryonic development as a function of temperature and relative humidity $(\mathrm{RH}), 4)$ larval growth (weight gain) and behavior, 5) correlation between adult wasp and host sizes (weight), and 6) ontogenetic changes in larval feeding patterns.

\section{Description of the Study AreA}

Studies were conducted on wasps located within a $7-\mathrm{km}$ radius of Study Butte (Brewster Co., Texas; $32^{\circ} 24^{\prime} \mathrm{N}, 103^{\circ} 12^{\prime} \mathrm{W}$; elevation: $920 \mathrm{~m}$ ), located within the northern region of the Chihauhuan Desert. A detailed description of the geology and vegetational zones of this region is given by Tinkam (1948). The study area is characterized by a mixture of sand, gravel, and adobe soils associated with a predominantly sotol-lechuguilla community. The dominant vegetation consists of sotol (Dasylirion leiophyllum), 
lechguilla (Agave lechuguilla), creosote (Larrea divaricata), mesa sacahuista (Nolina erumpens), tarbrush (Flourensia cernua), mesquite (Prosopis glandulosa), catclaw (Acadia roemeriana), Mexican jara (Bacharis glutinosa), saltbush (Atriplex cunescens), ocotillo (Fouquieria splendens), and scattered clumps of chino grass (Bouteloua breviseta). In this region, Pepsis thisbe females are host-specific on the tarantula spider, Aphonopelma echina Chamberlin (Orthogntha: Theraphosidae). Males and females of the host are strongly fossorial and construct or occupy burrows primarily in adobe soils. The burrows are usually located at the base of clumps of grass or mesquite.

\section{MATERIALS AND METHODS}

Adult wasps were collected with sweep nets. Eggs, larvae, and pupae of $P$. thisbe were collected from the burrows of parasitized spiders as described by Punzo and Garman (1989). Statistical methods used throughout this study follow those described by Sokal and Rohlf (1981).

A Unitron Model 110A dissecting microscope fitted with an ocular micrometer was used to measure the length and width of wasp eggs $(\mathrm{N}=1235)$ as well as body length, forewing length, and head capsule width of adult males $(\mathrm{N}=307)$ and females $(\mathrm{N}=$ 235). Forewing length was measured from the base of the wing to the outermost edge as described by Alcock (1979). Egg weight was determined using a Mettler electronic balance. All egg measurements were conducted on eggs immediately following their attachment to the host spider. A random sample of 200 gravid female wasps collected in the field was used to determine mean potential fecundity (number of eggs/female). Females were anesthetized with carbon dioxide and the ovarioles dissected in order to determine fecundity.

I also conducted a series of experiments to determine the combined effect of temperature and relative humidity $(\mathrm{RH})$ on the survivorship and duration of embryonic and postembryonic development for eggs and all larval instars (L1-L5) of $P$. thisbe. The protocol for these experiments was similar to that described by Punzo and Mutchmor (1980). Eggs and larvae were exposed to both mesic $(70 \% \mathrm{RH})$ and xeric $(10 \% \mathrm{RH})$ conditions at test temperatures of 20 and $30^{\circ} \mathrm{C}$. These values represent non-stressful as 
well as stressful conditions and are within the range of values observed in the study area. Five replications of 10 eggs or larvae $(\mathrm{N}=50)$ were exposed to each combination of temperature and RH. All experiments were conducted under constant darkness (to simulate sealed burrow conditions) in a Percival Model I-35VL Environmental Chamber (Boone, Iowa) which allowed for precise temperature, $\mathrm{RH}$, and photoperiod control. Ten fertilized eggs were placed on a piece of filter paper (Whatman No. 3) lining the bottom of a glass petri dish and then placed in the environmental chamber and allowed to develop. The percent surviving and hatching into first instar larvae was recorded.

I obtained larvae from eggs deposited on host spiders during laboratory encounters between wasp and host as described by Punzo and Garman (1989) for the wasp, P. formosa. After hatching, individual larvae and their hosts were placed in glass finger bowls in the environmental chamber and the duration (hr) and percent survival of each larval instar was recorded. Larval instars were identified following each molt.

Additional parasitized hosts were used to obtain wasp larvae for observation of larval feeding patterns in the laboratory. After eclosion, 50 first-instar larvae were observed carefully using a handheld magnifying glass $(5 x)$ as well as a dissecting microscope. Their feeding behavior was recorded photographically with a Nikon FE2 35mm camera and a Panasonic L3 video recorder. A Lafayette Analyzer (Model 1026) was used for frame-by-frame analyses. Ontogenetic changes in feeding patterns (host tissues selectively consumed) were analyzed throughout larval development. Larvae were also weighted $24 \mathrm{hr}( \pm 2 \mathrm{hr}$ ) prior to each molt in order to determine larval weight gain as a function of development.

These data were compared to growth rates obtained for 50 developing larvae in the field. Female wasps were observed searching for Aphonopelma echina burrows. Once an occupied spider burrow was located and the host parasitized, the burrow was monitored every $48 \mathrm{hr}$. The burrow entrances were opened by removing packed soil with a metal spatula and the parasitized hosts removed from the nest. The larvae were gently removed from the host with a camel hair brush and weighed on a Sartorius electronic balance operated with a $110 \mathrm{~V}$ portable power supply. After weighing, larvae 
were returned to the same location on the host from which they were removed, and allowed to resume feeding. The hosts with attached larvae were then placed back in the burrow and the entrance closed until the next observation.

I conducted additional laboratory experiments to determine the relationship between the size of the adult wasp (total body length) and the size (weight) of the host on which the larva fed. The weight $(\mathrm{g})$ of 40 hosts was measured between 3-5 hr prior to parasitization. Wasp larvae were allowed to develop on the host and pupate at $21^{\circ} \mathrm{C}$ and $70-75 \% \mathrm{RH}$. After emergence, adult wasps were anesthetized with carbon dioxide and their total body length (mm) measured. Wasps were anesthetized to prevent any movement; this resulted in reliable and accurate (standardized) length measurements.

\section{RESULTS}

\section{Reproductive And Developmental Parameters}

The mean potential fecundity was 13.4 eggs/female with a range of 9-17. Mean values for egg length $(4.7 \mathrm{~mm} ; \pm 0.3 \mathrm{~S}$.D. $)$, width $(1.4 \mathrm{~mm} ; \pm 0.2)$ and weight $(7.3 \mathrm{mg} ; \pm 0.8)$ are similar to those reported for $P$. marginata from Puerto Rico (Petrunkevtch, 1952) and $P$. formosa from Arizona (Cazier and Mortenson, 1964).

The morphometric data for adult $P$. thisbe males and females are listed in Table 1. Sexual dimorphism with respect to body size is common in Pepsis wasps (Hurd, 1952; Evans and Yoshimoto, 1962). In $P$. thisbe, body size ranges from $18.7-24.8 \mathrm{~mm}$ for males, and 27.1-38.7 for females.

The eggs and larvae of $P$. thisbe are intolerant of xeric conditions (Table 2). These developmental stages exhibited $100 \%$ mortality when exposed to $10 \% \mathrm{RH}$ regardless of ambient temperature. This is not surprising because all larval stages are characterized by a very thin and lightly chitinized integument that is not a very efficient barrier to evaporative water loss. In the field, moisture is usually not a limiting factor since $\mathrm{RH}$ in sealed burrows is relatively high (68-77\%).

Moisture and temperature had a significant effect $(\mathrm{F}=19.2 ; \mathrm{df}=$ 5122; $\mathrm{p}<0.01$ ) on the duration of embryonic development (Table 2). The mean time required for fertilized eggs to complete development 
Table 1. Morphological dimensions (mm) for adult Pepsis thisbe males and females. Values represent means \pm S.D. Values in parentheses represent the range.

\begin{tabular}{lcccc}
\hline Sex & N & $\begin{array}{c}\text { Body } \\
\text { length }\end{array}$ & $\begin{array}{c}\text { Head capsule } \\
\text { width }\end{array}$ & $\begin{array}{c}\text { Wing } \\
\text { length }\end{array}$ \\
\hline Males & \multirow{2}{*}{307} & $22.3 \pm 2.1$ & $3.2 \pm 0.4$ & $21.9 \pm 1.6$ \\
& & $(18.7-24.8)$ & $(2.7-3.3)$ & $(17.2-23.1)$ \\
Females & 235 & $\begin{array}{c}29.6 \pm 3.2 \\
(27.1-38.7)\end{array}$ & $\begin{array}{l}4.4 \pm 0.3 \\
(3.7-4.5)\end{array}$ & $\begin{array}{c}24.9 \pm 2.8 \\
\end{array}$ \\
\hline
\end{tabular}

${ }^{1}$ Forewing length measured from base of forewing to the outermost edge as described by Alcock (1979)

Table 2. Duration (hr) of embryonic and postembryonic development and percent survival for various life cycle stages of Pepsis thisbe exposed to various conditions of temperature $\left({ }^{\circ} \mathrm{C}\right)$ and relative humidity $(\% \mathrm{RH}) . \mathrm{N}=50$ eggs, larvae or pupae were exposed to each condition of temperature and $\mathrm{RH}$.

\begin{tabular}{lccc}
\hline Stage & ${ }^{\circ} \mathrm{C} / \mathrm{RH}^{1}$ & $\begin{array}{c}\text { Mean duration } \\
\text { (hr) }( \pm \text { S.D. })\end{array}$ & $\begin{array}{c}\text { Percent } \\
\text { survival }\end{array}$ \\
\hline Egg & $20^{\circ} / 10 \%$ & - & 0 \\
& $30^{\circ} / 10 \%$ & - & 0 \\
& $20^{\circ} / 70 \%$ & $187.6(17.2)$ & 74 \\
First larval instar & $30^{\circ} / 70 \%$ & $102.4(10.1)$ & 68 \\
& $20^{\circ} / 70 \%$ & $76.4(9.2)$ & 72 \\
Second larval instar & $30^{\circ} / 70 \%$ & $50.4(6.7)$ & 74 \\
& $20^{\circ} / 70 \%$ & $88.3(11.6)$ & 76 \\
Third larval instar & $30^{\circ} / 70 \%$ & $59.7(7.8)$ & 70 \\
& $20^{\circ} / 70 \%$ & $105.6(14.4)$ & 72 \\
Fourth larval instar & $30^{\circ} / 70 \%$ & $84.3(7.7)$ & 66 \\
& $20^{\circ} / 70 \%$ & $156.2(17.1)$ & 68 \\
Fifth larval instar & $30^{\circ} / 70 \%$ & $121.4(11.6)$ & 74 \\
& $20^{\circ} / 70 \%$ & $163.2(13.7)$ & 76 \\
Pupal stage & $30^{\circ} / 70 \%$ & $135.2(10.3)$ & 68 \\
& $20^{\circ} / 70 \%$ & $504.3(32.2)$ & 80 \\
& $30^{\circ} / 70 \%$ & $432.7(18.7)$ & 74 \\
\hline
\end{tabular}

${ }^{1}$ There was $100 \%$ mortality of all life cycle stages exposed to xeric (10\% RH) conditions

${ }^{2}$ ANOVA showed an overall significant effect of temperature on duration of development $(\mathrm{F}=19.2, \mathrm{df}=5,122 ; \mathrm{p}<0.01)$ 
was 102.4 and $187.6 \mathrm{hr}$ at temperatures of 20 and $30^{\circ}$, respectively). The amount of time required from the moment of oviposition to the formation of the cocoon by fifth instar larvae ranged from 553.4-777.3 $\mathrm{hr}$ (23-32 days). Pepsis thisbe has five larval instars in its life cycle (L1-L5). The mean duration for the pupal stage ranged from $432.7-504.3 \mathrm{hr}$.

Approximately 4-5 days after oviposition, a small area at the free end of the cream-colored egg begins to turn white. A pair of dark mandibles can be seen at this time through the thin egg shell. The shell then splits open revealing the first instar larva which is white in coloration. Its posterior end is attached to the ventral area of the host abdomen near the book lungs. The larva curves the anterior end of its body foreward until the head capsule makes contact with the host and begins to feed. With the exception of changes in size, no significant morphological differences exist between larval instars 1-4 although the head capsule becomes more heavily chitinized and darker brown in coloration. At the end of $\mathrm{L} 1$, larvae range from $7.1-8.8 \mathrm{~mm}$ and weigh $310-327 \mathrm{mg}$, depending on ambient temperature. The mean weights for subsequent larval instars under both field and laboratory conditions are shown in Table 3. No significant differences in growth rates were found between laboratory and field conditions $(\mathrm{F}=1.56 ; \mathrm{p}>0.5)$. Larval weight increased from $310-327 \mathrm{mg}$ at the end of the L1 stage to over $1460 \mathrm{mg}$ (length: $21.3-30.8 \mathrm{~mm}$ ) just before cocoon formation (L5). Following the fourth molt, the last larval instar (L5) emerges and exhibits some obvious morphological changes. The previously pointed mandibles are thicker and possess deeper toothed ridges. The spiracles are markedly larger. It is during this stage that the host is finally killed.

Table 3. Weight gain (mg) as a function of development for various larval instars (L1-L5) of Pepsis thisbe $(\mathrm{N}=50)$ under both laboratory and field conditions. Values represent means ( \pm S.D.).

\begin{tabular}{ccr}
\hline Larval Instar & Laboratory Conditions & Field Conditions \\
\hline 1 & $322.2(24.6)$ & $337.3(31.2)$ \\
2 & $427.5(34.3)$ & $419.3(19.5)$ \\
3 & $1208.3(48.9)$ & $1221.6(38.7)$ \\
4 & $1385.6(58.3)$ & $1369.4(70.1)$ \\
5 & $1489.7(80.2)$ & $1468.4(69.4)$ \\
\hline
\end{tabular}




\section{Larval Feeding Patterns And Pupation}

Upon emergence, the first instar larva uses its mandibles to break through the host integument in the vicinity of the book lungs and begins to feed on cuticular lamellae and underlying connective tissues. This occupies the first 3-7 hr of feeding. The ontogenetic changes in larval feeding patterns are outlined in Table 4. It should be noted that only in the last larval instar are vital host tissues (heart and nerve) ingested.

Table 4. Ontogenetic changes in feeding patterns for larvae of Pepsis thisbe. Data indicate host spider tissues progressively consumed by wasp larvae as a function of time (hr) following hatching. Observations based on 50 developing larvae.

\begin{tabular}{|c|c|c|}
\hline Stage $^{1}$ & $\begin{array}{l}\text { Hours after } \\
\text { hatching }\end{array}$ & Spider tissues ingested \\
\hline \multirow[t]{3}{*}{ L1 } & $0-7$ & $\begin{array}{l}\text { Meso- and endo-cuticular lamellae } \\
\text { of the abdomen and associated } \\
\text { underlying connective tissues }\end{array}$ \\
\hline & $7-24$ & $\begin{array}{l}\text { Underlying cuticular longitudinal } \\
\text { muscles of the abdomen }\end{array}$ \\
\hline & $24-70$ & $\begin{array}{l}\text { Medial region of the midgut and } \\
\text { dorsal region of the ovaries }\end{array}$ \\
\hline L2 & $76-150$ & $\begin{array}{l}\text { L1 moves posteriorly and begins to } \\
\text { ingest posterior region of the gut, } \\
\text { ovaries, and associated muscles } \\
\text { and connective tissues }\end{array}$ \\
\hline \multirow[t]{2}{*}{ L3 } & $160-180$ & $\begin{array}{l}\text { Movement anteriorly to ingest } \\
\text { anterior regions of the gut and } \\
\text { ovaries, spinning glands, and book } \\
\text { lungs }\end{array}$ \\
\hline & $190-250$ & $\begin{array}{l}\text { Intestine, abdominal nerves, } \\
\text { midgut diverticulum, pharynx } \\
\text { elevator musculature }\end{array}$ \\
\hline \multirow[t]{2}{*}{ L4 } & $270-370$ & $\begin{array}{l}\text { Pharynx elevator and depressor } \\
\text { musculature }\end{array}$ \\
\hline & $370-410$ & $\begin{array}{l}\text { Connective tissues of the prosoma, } \\
\text { esophagus, sucking stomach }\end{array}$ \\
\hline L5 & $425-560$ & $\begin{array}{l}\text { Tissues of the subesophageal and } \\
\text { supraesophageal ganglia, and the } \\
\text { heart }\end{array}$ \\
\hline
\end{tabular}

${ }^{1}$ Larval stages 1 through 5 (L1-L5) 
The larva uses the remains of the host as a substrate for cocoon formation. At the end of L5, the larva spins a very thin outer capsule which will support the finished cocoon. Silk emanates from labial silk glands. Silk strands are attached to the spider integument and then slowly worked around the body of the larva starting at its posterior end. After $28-34 \mathrm{hr}$ the larva is completely concealed by a thin silk covering. At this time, the larval meconium is discharged and forms a hardened mass at the posterior end of the body. The cocoon becomes progressively thicker and darker.

Observations in the field indicate that in this study area, cocoon formation can occur from early July through September. If cocoons were formed in early summer, adults will emerge, mate, and search for hosts during the same season. If cocoon formation does not occur until late summer or early fall, wasps will overwinter in the cocoon stage.

\section{Correlation Between Adult Wasp Size And Host Weight}

There is a significant correlation between adult wasp body length and the weight of the host spider $(r=0.924, p<0.01)$. This relationship is shown in Fig. 1. The regression equation is: $y=$ $.43 \mathrm{x}-4.705$. Data points for wasp sizes below $27 \mathrm{~mm}$ represent males; those above this value represent females. Wasp body size increased significantly with increasing host weight (regression: $\mathrm{r}^{2}=0.91, \mathrm{p}<0.001, \mathrm{~N}=40$ ).

\section{Discussion}

The low fecundity that characterizes this pompilid species reflects the highly efficient hunting strategy characteristic of this genus (Punzo, 1991). The high survival rates of eggs and larvae of $P$. thisbe observed in the field and laboratory suggest that this wasp is well adapted to its environment. Once an egg is deposited on a paralyzed host and the burrow entrance sealed, mortality rates are less than $35 \%$, ensuring a high percentage of emerging adults. Stomach content analyses of potential predators have not reported this wasp. Apparently the adult wasps have few natural predators. Twice I observed a roadrunner (Geococcyx californianus) attacking a wasp on the ground. The bird grasped the wasp with its beak and beat it against the substrate prior to ingestion. I have not seen one 


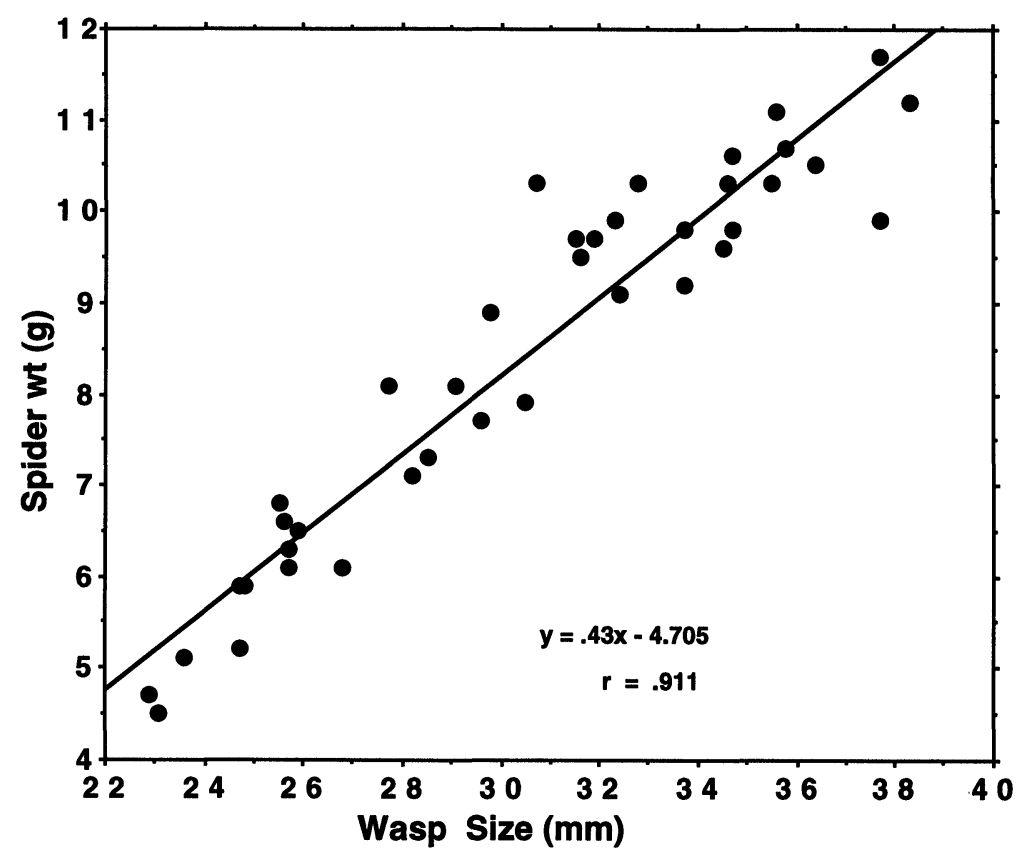

Fig. 1. Relationship between the total body length (mm) of Pepsis thisbe adults and the weight of the host spider, Aphonopelma echina. Values $<27 \mathrm{~mm}$ represent males; > $27 \mathrm{~mm}$, females.

of these wasps captured in any of the spider webs frequently encountered in this area. In over 400 encounters observed between a female wasp and its tarantula host in the field, on only one occasion have I witnessed a spider successfully biting, penetrating, and killing a wasp. These wasps have heavily sclerotized bodies that appear to be relatively resistant to penetration by the (spider) fangs even though the incidence of the host actually attempting to strike at the wasp is rare (Punzo and Garman, 1989). Although male and female Pepsis wasps frequently engage in inter- and intra-specific territorial contests (Williams, 1956; Alcock, 1983; Field, 1992), these disputes are rarely fatal.

The results of this study have shown a strong correlation between adult wasp size and the weight of the host that was consumed. The question remains as to whether or not a larger body size confers any selective advantage to adult wasps. There was also 
a wide range of adult body sizes for both sexes in this population. Why do smaller individuals persist? The males are strongly territorial and will aggressively defend perch sites on mesquite, ocotillo, and various trees by aerial combative contests with conspecific males that stray too close. Males will alight on a perch site and wait for females to fly through their territory. I have witnessed a male copulating with a female on only five occasions. Although viewed from a distance through binoculars, in each case copulation occurred when a female landed near the perch site of a male. Although there is no experimental evidence yet available for members of this genus, studies on Diptera and Lepidoptera (Shields, 1967) as well as the closely related Hemipepsis wasps (Alcock, 1979), suggest that larger males are more successful in gaining and holding perch sites most conductive to successful mating. Larger males tend to occupy perch sites both at higher elevations ("hilltopping," Shields, 1967) and on taller vegetation which appear to be more attractive to females. Alcock (1978) has suggested that hilltopping behavior in the pompilid $H$. ustulata evolved because it facilitates the ability of a male to locate and monopolize emerging virgin females that are characterized by unpredictable and erratic dispersal patterns. Once hilltopping behavior evolved, selection should favor females who could choose the best possible mate. In insects such as pompilid wasps, where males make no parental investment in their progeny, female mate choice may be based primarily on social dominance (Emlen and Oring, 1977; Thornhill and Alcock, 1983). Social dominance is often correlated with body size in many animal groups (Daly, 1978; Berry and Shine, 1980). Dominance status can be communicated through the competitive ability of larger males to exclude conspecifics from their territories. Perhaps males occupying higher perch sites are capable of monitoring a broader area for the presence of females.

If this holds true for $P$. thisbe males, why is there a rather wide variation in size $(18.7-24.8 \mathrm{~mm})$ maintained in the population? In solitary wasps, adult size is determined by the maternal parent (Evans, 1953). This study has shown that the size of a $P$. thisbe adult is determined by the size of the host that was provided for that wasp by its mother. Therefore, the seasonal frequency distribution of host size classes in a given area will determine the size variation found in adult wasps. 
What about the size variation exhibited by female wasps $(27.1-38.7 \mathrm{~mm})$ ? Once again, female size will be a function of the size distribution for available hosts in a given area. Do larger females have an advantage over smaller individuals? Perhaps larger females are capable of storing more nutrient reserves and can therefore travel over greater distances in search for hosts. In addition, there is no experimental evidence yet available to support the hypothesis that larger females might experience greater success at attacking larger spiders. It would also be interesting to determine if host selection is random or if it is directly influenced by the size of the wasp.

\section{ACKNOWLEDGEMENTS}

I thank James Bottrell and Thomas Punzo for assistance in the collection and monitoring of wasps and spiders in the field, and Brian Garman, Dept. of Mathematics, and Ali Jenzarli, College of Business, for consultation on statistical analyses. I also thank the University of Tampa for a Faculty Development Grant which made much of this work possible, and anonymous reviewers for comments on an earlier draft of the manuscript. Finally, I would like to thank the Dean of the College of Liberal Arts and Sciences, Terry Parssinen, for his support and encouragement of scholarly activities.

\section{Literature Cited}

Alcock, J. 1978. Notes on male mate-locating behavior in some bees and wasps of Arizona (Hymenoptera: Anthophoridae, Pompilidae, Sphecidae, Vespidae). PanPac. Ent. 54:216-225.

Alcock, J. 1979. The behavioral consequences of size variation among males of the territorial wasp, Hemipepsis ustulata (Hymenoptera: Pompilidae). Behavior 71:322-335.

Alcock, J. 1983. Consistency in the relative attractiveness of a set of landmark territorial sites to two generations of male tarantula hawk wasps (Hymenoptera: Pompilidae). Anim. Behav. 31:74-80.

Berry, J. F. and R. Shine. 1980. Sexual size dimorphism and sexual selection in turtles (Order Testudines). Oecologia 44:185-191.

Cazier, M. A. and M. Mortenson. 1964. Bionomical observations on tarantula hawks and their prey (Hymenoptera : Pompilidae): Pepsis. Ann. Ent. Soc. Amer. 57:533-541.

Daly, M. 1978. The cost of mating. Amer. Nat. 112:771-774.

Emlen, S. T. and L. W. Oring. 1977. Ecology, sexual selection and the evolution of mating systems. Science 197:215-233. 
Evans, H. E. 1953. Comparative ethology and the systematics of spider wasps. Syst. Zool. 2: 155-172.

Evans, H. E. and C. M. Yoshimoto. 1962. The ecology and nesting behavior of the Pompilidae (Hymenoptera) of the Northeastern United States. Misc. Publ. Ent. Soc. Amer. 3:67-120.

Field, J. 1992. Guild structure in solitary spider-hunting wasps (Hymenoptera : Pompilidae) compared with null model predictions. Ecol. Entomol. 17:198-208.

Hurd, P. D. 1952. Revision of the Nearctic species of the pompilid genus Pepsis (Hymenoptera : Pompilidae). Bull. Amer. Mus. Nat. Hist. 98:261-334.

Passmore, L. 1936. Tarantula and tarantula hawk. Nat. Mag. 27:155-159.

Petrunkevitch, A. 1926. Tarantula versus tarantula hawk: a study in instinct. J. Exp. Zool. 45:367-394.

Petrunkevitch, A. 1952. The spider and the wasp. Sci. Amer. 187:20-33.

Punzo, F. 1990. The hemolymph composition and neurochemistry of the spider wasp, Pepsis formosa (Hymenoptera : Pompilidae). Comp. Biochem. Physiol. 96A:341-345.

Punzo, F. 1991. Neurochemical events associated with learning and hunting behavior in the spider wasp, Pepsis formosa (Say) (Hymenoptera : Pompilidae). Fla. Scient. 54:51-61.

Punzo, F. and B. Garman. 1989. Effects of encounter experience on the hunting behavior of the spider wasp. Pepsis formosa (Say) (Hymenoptera : Pompilidae). Southwest. Nat. 34:513-518.

Punzo, F. and J. A. Mutchmor. 1980. Effects of temperature, relative humidity and period of exposure on the survival capacity of Tenebrio molitor (Coleoptera : Tenebrionidae). J. Kansas Entomol. Soc. 53:260-270.

Shields, O. 1967. Hilltopping. J. Lepid. Res. 6:69-178.

Sokal, R. R. and F. J. Rohlf. 1981. Biometry. 2nd ed., W. H. Freeman and Company, New York.

Thornhill, R. and J. Alcock. 1983. The Evolution Of Insect Mating Systems. Harvard University Press, Cambridge, Massachusetts.

Tinkam, E. R. 1948. Faunistic and ecological studies on the Orthoptera of the Big Bend Region of Trans Pecos Texas. Amer. Midl. Nat. 40:521-563.

Williams, F. X. 1956. Life history studies of Pepsis and Hemipepsis wasps in California (Hymenoptera : Pompilidae). Ann., Ent. Soc. Amer. 49:447-466. 

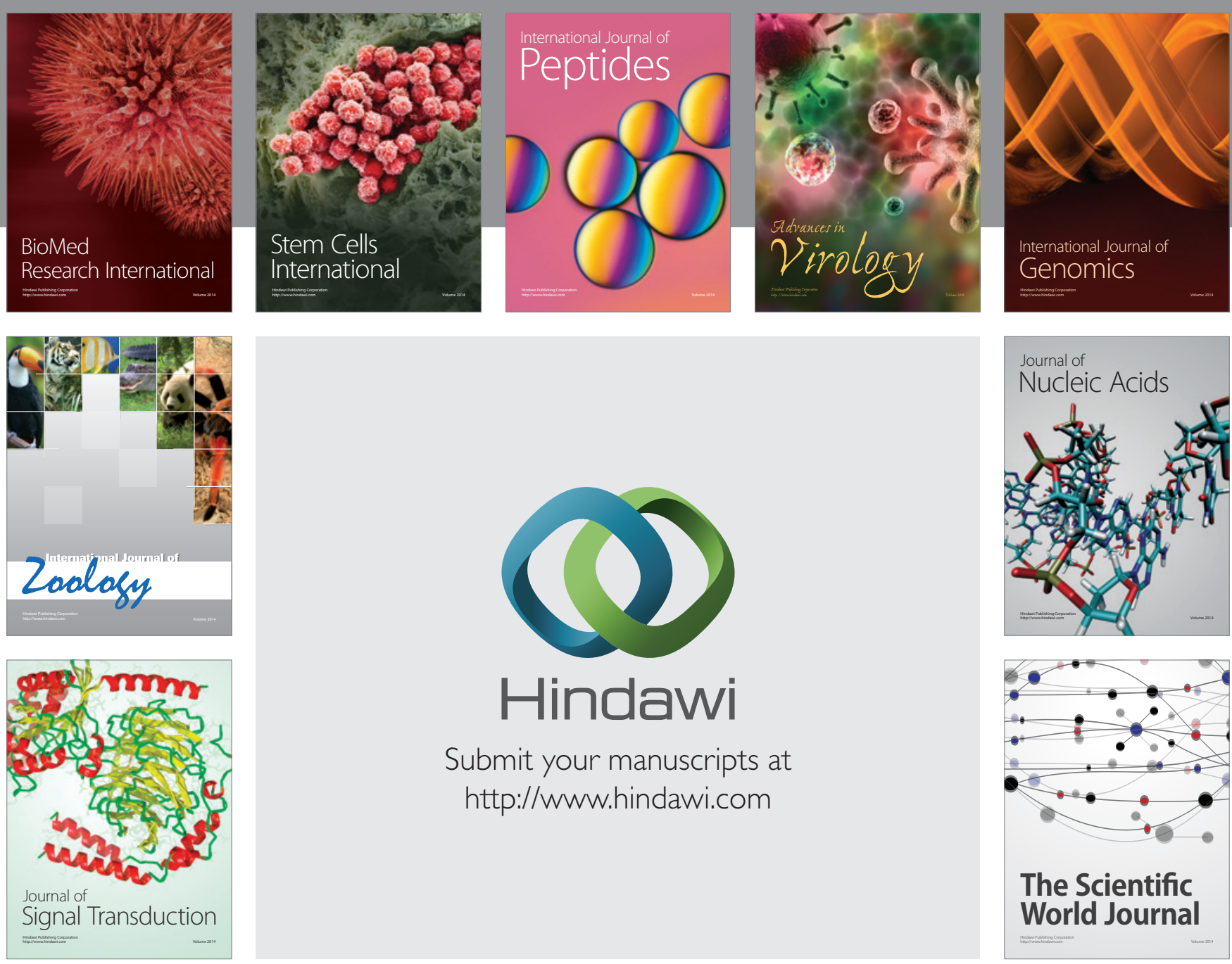

Submit your manuscripts at

http://www.hindawi.com
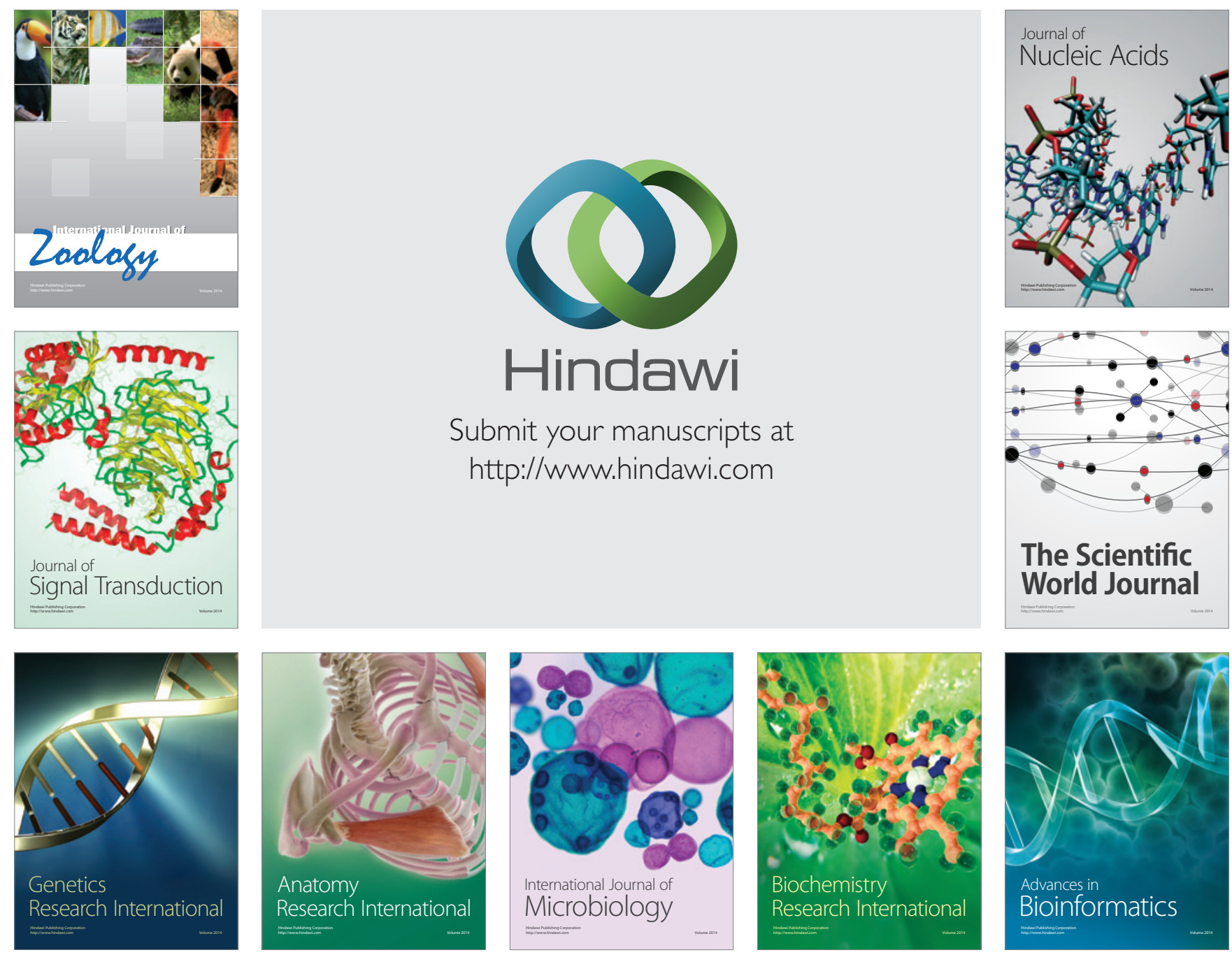

The Scientific World Journal
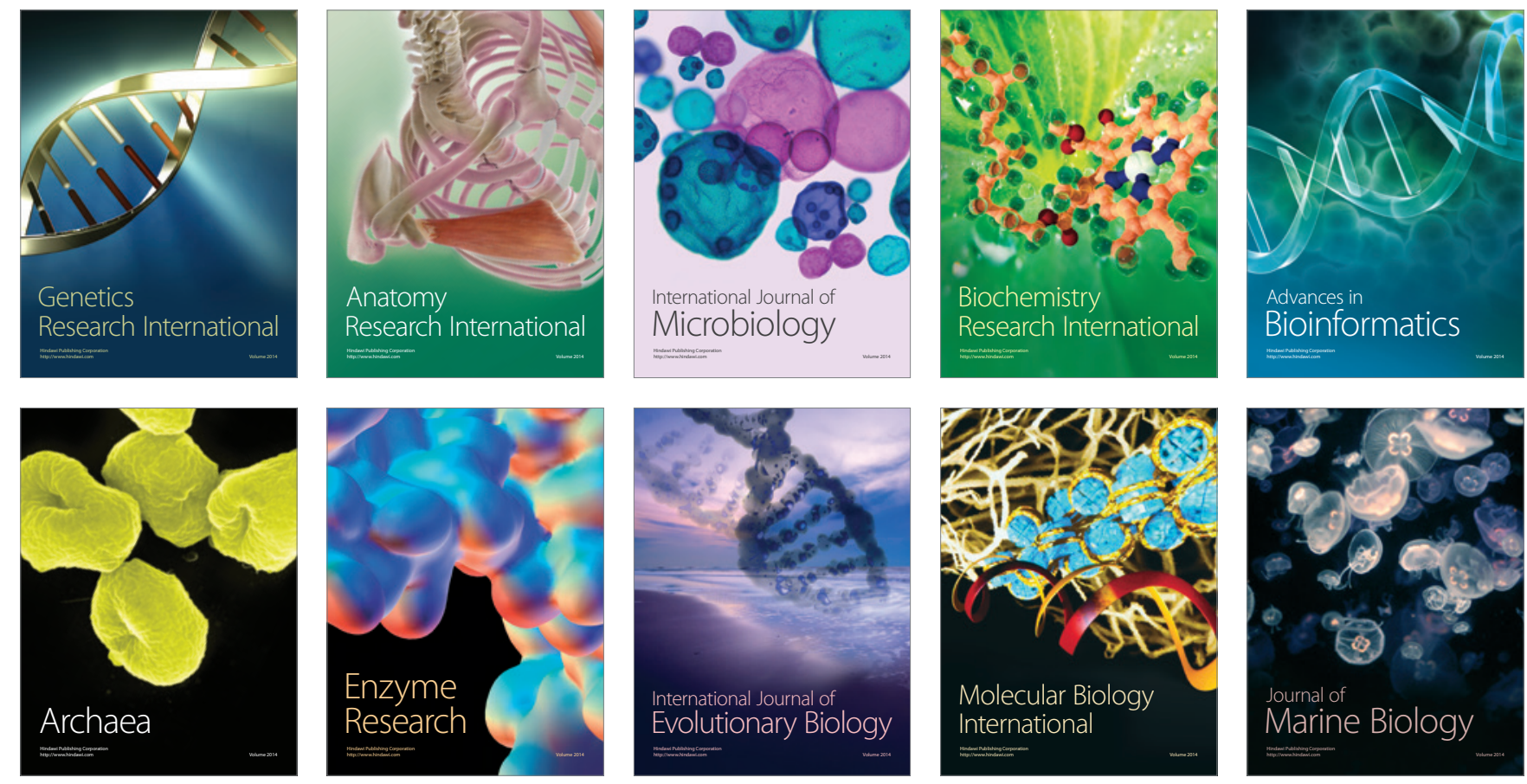